\title{
OHMIC CONACTS TO p-GaN ON THE BASIS OF CARBON NANOMATERIALS
}

\author{
Jozef Liday $^{*}$ - Peter Vogrinčič ${ }^{*}$ - Viliam Vretenár ${ }^{* *}$ - Mário Kotlár ${ }^{*}$ \\ - Marián Marton * Miroslav Mikolášek ${ }^{*}$ - Vlastimil Řeháček*
}

\begin{abstract}
We have designed and verified a new structure for ohmic contacts to p-GaN based on a layer of carbon nanotubes (CNT), reduced graphene oxide ( $\mathrm{r}-\mathrm{GO}$ ) and metallic layers of $\mathrm{Cr}$, $\mathrm{Pd}$ and $\mathrm{Au}$, namely in configurations $\mathrm{Au} / \mathrm{Cr} / \mathrm{r}-\mathrm{GO} / \mathrm{CNT} / \mathrm{p}-\mathrm{GaN}$ and $\mathrm{Au} / \mathrm{Pd} / \mathrm{r}-\mathrm{GO} / \mathrm{CNT} / \mathrm{p}-\mathrm{GaN}$. The effects have been studied of the annealing temperature and the gas ambient upon the electrical properties of the contacts. Annealing of the $\mathrm{Au} / \mathrm{Pd} / \mathrm{r}-\mathrm{GO} / \mathrm{CNT} / \mathrm{p}-\mathrm{GaN}$ structure in air at $500^{\circ} \mathrm{C}$ for 1 minute resulted in linear $I-V$ curves measured between planar electrodes on the p-GaN. Hence, addition of r-GO to the CNT interlayer between p-GaN and the metallization layer is a highly promising procedure for further improvements of the ohmic contacts to $\mathrm{p}-\mathrm{GaN}$
\end{abstract}

K e y w or d s: p-GaN, ohmic contacts, carbon nanotubes (CNT), reduced graphene oxide (r-GO)

\section{INTRODUCTION}

Even though remarkable advances have been reached recently in the use of gallium nitride based semiconductor compounds as short wavelength light emitting materials, there are still several factors limiting the reliability and performance of these devices. One of these issues is the low level of doping of p-GaN attainable by standard techniques, which hinders reaching a satisfactorily high hole concentration $\left(>10^{18} \mathrm{~cm}^{-3}\right),[1]$. Therefore ohmic contacts to p-type GaN still constitute a problem. For efficient charge transport such devices require good ohmic contacts with low resistance.

For improving the ohmic properties of the p-GaN contact, a number of metallization layouts had been used. Nevertheless, the $\mathrm{Au} / \mathrm{Ni} / \mathrm{p}-\mathrm{GaN}$ [2-5] structure seems to be the most suitable thanks to relatively good values of the specific contact resistance and optical transparency. By examining the effect of a $\mathrm{NiO}_{x}$ layer with a low concentration of oxygen upon the electrical properties of $\mathrm{Au} / \mathrm{NiO}_{x} / \mathrm{p}-\mathrm{GaN}$ ohmic contacts [6] it was found that a low-resistance ohmic contact was achieved by $\mathrm{Au} / \mathrm{NiO}_{x}$ layers deposited by reactive magnetron sputtering and annealed not only in oxygen but also in nitrogen. Both annealing modes lead to reconstruction of the contact structure into a metal/p-NiO/p-GaN structure. The ohmic nature of these contacts is predetermined by formation of a thin oxide layer $(\mathrm{NiO})$ at the metal/p-GaN interface. Incorporation group II dopants $(\mathrm{Mg}, \mathrm{Zn})$ into the Ni metallization layer intended to increase the charge carrier concentration in the surface region of $\mathrm{p}-\mathrm{GaN}$ resulted in lower values of the specific contact resistance than in the same structures without $\mathrm{Mg}$ and $\mathrm{Zn}$ dopants [7-9].
A highly promising procedure for obtaining low-resistance ohmic contancs to $\mathrm{p}-\mathrm{GaN}$ with excellent optical transparency might be the use of carbon nanomaterials (CNM), such as carbon nanotubes (CNT) and reduced graphene oxide (r-GO). Carbon nanotubes exhibit, depending on the orientation of the graphene plane, both semiconducting and metallic properties [10-13]. The first applications of CNT for ohmic contacts to p-GaN showed that the contact resistivity was lower than in the case of an $\mathrm{Au} / \mathrm{Ni}$ contact [11]. The study of contact structures $\mathrm{Au} / \mathrm{Cr} / \mathrm{SWCNT} / \mathrm{p}-\mathrm{GaN}$ and $\mathrm{Au} / \mathrm{Ni}-\mathrm{Mg}$ (O)/SWCNT/p-GaN [14] in which a layer of SWCNT was deposited between the metal and the layer of p-GaN revealed that the contact created by a layer of carbon nanotubes deposited on p-GaN by spray coating and covered by vapour deposited $\mathrm{Au} / \mathrm{Cr}$ or by reactive magnetron sputtering in an atmosphere with and without a low concentration of oxygen (approx. 0.2 at\%) deposited $\mathrm{Ni}-\mathrm{Mg} / \mathrm{Au}$ resulted in a lower resistivity ohmic contact in comparison with an identical contact structure without the SWCNT interlayer. It is believed that the ohmic nature is related to the existence of a contact scheme $\mathrm{metal} / \mathrm{p}-\mathrm{SWCT} / \mathrm{p}-\mathrm{GaN}$.

The topic of this work is the design and verification of a new ohmic contact structure to p-type GaN, based on a CNT layer, r-GO and metallic layers of $\mathrm{Cr}, \mathrm{Pd}$ and $\mathrm{Au}$. The quality of contacts in terms of their good ohmic behaviour was evaluated by I-V curve measurements. The influence was investigated of the annealing temperature in nitrogen and air ambients upon the quality of the prepared contacts.

Institute of Electronics and Photonics, Slovak University of Technology, Ilkovičova 3, 81219 Bratislava, Slovakia, jozef.liday@stuba.sk ** Danubia NanoTech, s.r.o., Ilkovičova 3, 84104 Bratislava, Slovakia 


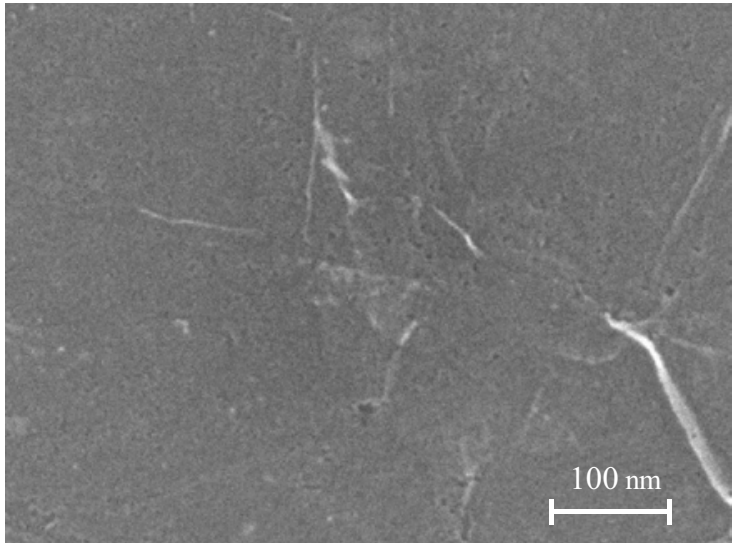

Fig. 1. SEM micrograph of the surface morphology of the r$\mathrm{GO} / \mathrm{CNT} / \mathrm{p}-\mathrm{GaN}$ structure

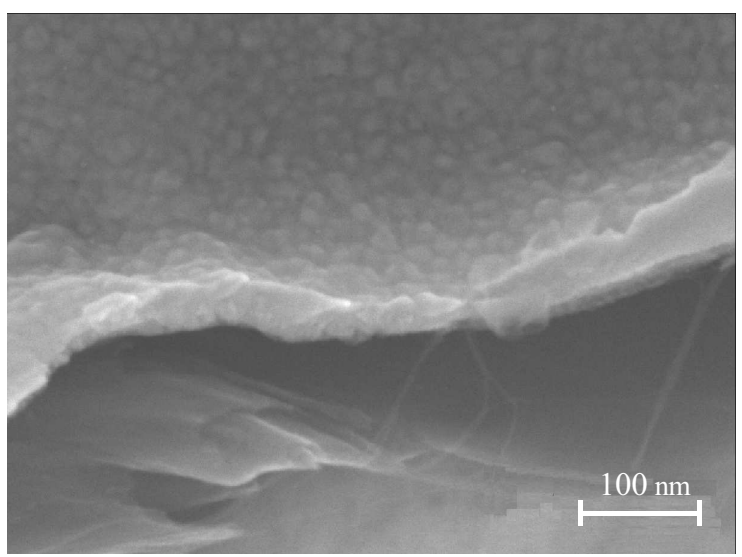

Fig. 3. Cross-sectional SEM micrograph of the $\mathrm{Au} / \mathrm{Cr} / \mathrm{r}-\mathrm{GO} / \mathrm{CNT}$ layer structure

\section{EXPERIMENTAL}

Metalorganic vapour phase epitaxy (MOVPE) p-GaN layers with a thickness of $800 \mathrm{~nm}$, carrier concentration $2 \times 10^{17} \mathrm{~cm}^{-3}$ and mobility around $5 \mathrm{~cm}^{2} /$ Vs produced in the Magnetic Spin Materials Group at Johannes Kepler University in Linz were used for preparation of $\mathrm{Au} / \mathrm{Cr} /$ r-GO/ CNT/p-GaN and $\mathrm{Au} / \mathrm{Pd} / \mathrm{r}-\mathrm{GO} / \mathrm{CNT} / \mathrm{p}-\mathrm{GaN}$ structures. The p-GaN layers were first sequentially ultrasonically treated for 5 minutes in each step in acetone, isopropanol, DI water, dried with compressed N2 and then chemically etched in $\mathrm{HCl}: \mathrm{H}_{2} \mathrm{O}$ (1:1) etchant to remove the surface native oxide. On such p-GaN layers, both CNT and graphene oxide layers were consecutively deposited by spray coating using an off-the-shelf airbrush. The high-quality CNT were prepared by the laser ablation method followed by a purification process. For spraying deposition, a solution of $2 \mathrm{mg}$ of CNT diluted with $20 \mathrm{ml}$ of N-methyl-2-pyrolidone was tip-sonicated for 10 minutes. The substrate was heated to $165^{\circ} \mathrm{C}$ in order to accelerate the evaporation of the solvent and prevent formation of bigger droplets. The thickness of the

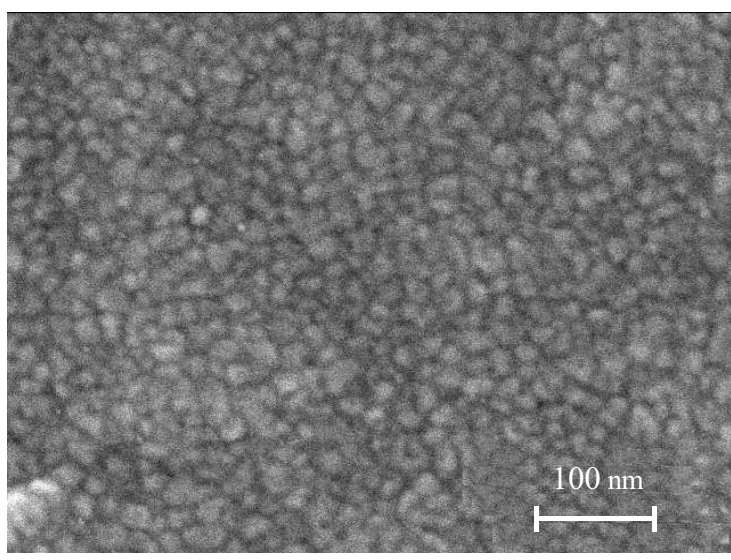

Fig. 2. SEM micrograph of the surface morphology of the $\mathrm{Au} / \mathrm{Cr} / \mathrm{r}-\mathrm{GO} / \mathrm{CNT} / \mathrm{p}-\mathrm{GaN}$ structure

CNT layer was approx. $30 \mathrm{~nm}$. For graphene layer, thermally reduced graphene oxide flakes were utilized. The graphene oxide flakes were prepared by chemical oxidation of graphite powder using the Hummer method modified by Jeong [15]. The synthesis method was described elsewhere [16]. The graphene oxide layer was deposited onto CNT layer using spraying technique. A solution of 2 $\mathrm{mg}$ of graphene oxide flakes diluted with $20 \mathrm{ml}$ of deionized water was tip-sonicated for $10 \mathrm{~min}$. During the deposition the substrate was heated to $105^{\circ} \mathrm{C}$. Such a layered structure $(\mathrm{GO} / \mathrm{CNT} / \mathrm{p}-\mathrm{GaN})$ was annealed in order to reduce the graphene oxide layer and to obtain finally the $\mathrm{r}-\mathrm{GO} / \mathrm{CNT} / \mathrm{p}-\mathrm{GaN}$ structure. Thermal reduction was performed by slow heating up to $850^{\circ} \mathrm{C}$ in nitrogen atmosphere for couple of hours. The thickness of the graphene layer was approx. $10 \mathrm{~nm}$.

The final step was deposition of metallic layers in two different contact structures, namely of $\mathrm{Cr}$ and $\mathrm{Au}$ in the contact structure $\mathrm{Au} / \mathrm{Cr} / \mathrm{r}-\mathrm{GO} / \mathrm{CNT} / \mathrm{p}-\mathrm{GaN}$, and of the $\mathrm{Pd}$ and $\mathrm{Au}$ in the case of contact structures $\mathrm{Au} / \mathrm{Pd} / \mathrm{r}-$ $\mathrm{GO} / \mathrm{CNT} / \mathrm{p}-\mathrm{GaN}$. Vapour deposition of the metallic layer was performed so as to get a contact structure suitable for current-voltage $(I-V)$ measurements. The contacts pads with a size of $0.5 \mathrm{~mm}$ were placed in the corners of a square-shaped sample with dimensions $6 \times 6 \mathrm{~mm}$. Thin films of $\mathrm{Cr}(10 \mathrm{~nm}), \mathrm{Pd}(10 \mathrm{~nm})$ and $\mathrm{Au}(50 \mathrm{~nm})$ were deposited by e-gun evaporation at a pressure of $10^{-4} \mathrm{~Pa}$. After deposition of the metal layers the GO/CNT was denuded by etching in RF oxygen plasma using Plasma Etch PE-200 equipment.

To study the effects of the annealing temperature and gaseous ambient upon the quality of the two types of contact structures, the $\mathrm{Au} / \mathrm{Cr} / \mathrm{r}-\mathrm{GO} / \mathrm{CNT} / \mathrm{p}-\mathrm{GaN}$ and $\mathrm{Au} / \mathrm{Pd} / \mathrm{r}-\mathrm{GO} / \mathrm{CNT} / \mathrm{p}-\mathrm{GaN}$ samples were annealed, immediately after deposition, in a rapid thermal annealing furnace at temperatures from $400{ }^{\circ} \mathrm{C}$ to $800^{\circ} \mathrm{C}$ in nitrogen and air atmosphere.

$I-V$ characterization of the structures was conducted using a computerized measuring system [17] designed for sheet resistance and Hall mobility measurements. This 


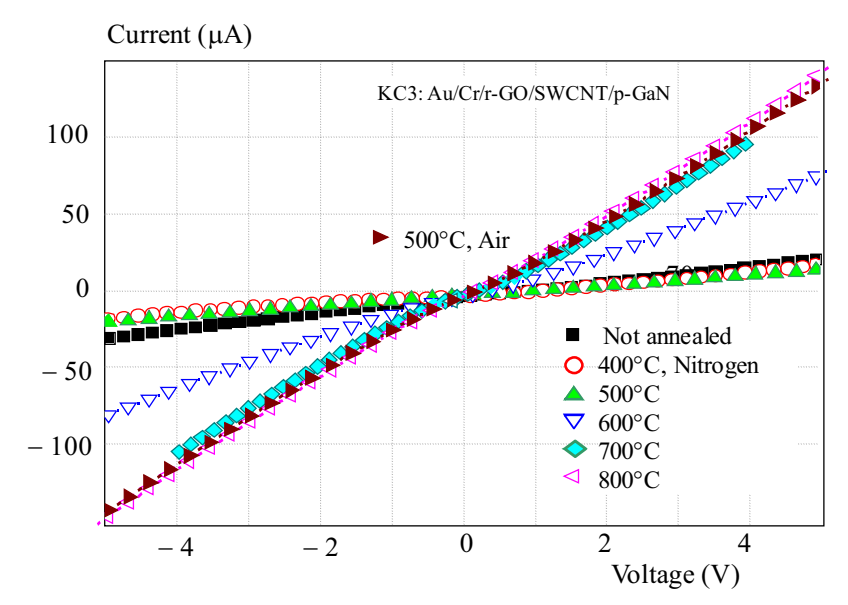

Fig. 4. $I-V$ curves of the $\mathrm{Au} / \mathrm{Cr} / \mathrm{r}-\mathrm{GO} / \mathrm{CNT} / \mathrm{p}-\mathrm{GaN}$ contact nonannealed and annealed in $\mathrm{N}_{2}$ at temperatures ranging from 400 to $800{ }^{\circ} \mathrm{C}$ and in air at $500{ }^{\circ} \mathrm{C}$ for 1 minute

system provides also $I-V$ measurements for inspection of quality of ohmic contacts.

\section{RESULTS}

SEM image of the surface of the r-Go/CNT layer deposited onto a p-GaN substrate (Fig. 1) shows a homogeneous structure of the layer. The thicknesses of the deposited r-Go/CNT and CNT layers examined by crosssectional SEM analysis were around $10 \mathrm{~nm}$ and $35 \mathrm{~nm}$. SEM micrograph an identical structure covered by metallic layers of $\mathrm{Au}(50 \mathrm{~nm})$ and $\mathrm{Cr}(10 \mathrm{~nm})$ is shown in Fig. 2. Figure 3 is a SEM micrograph of the cross-fracture of the same sample as shown in Fig. 2, thus of the contact structure $\mathrm{Au} / \mathrm{Cr} / \mathrm{r}-\mathrm{GO} / \mathrm{CNT} / \mathrm{p}-\mathrm{GaN}$.

The measured $I-V$ curves of the $\mathrm{Au} / \mathrm{Cr} / \mathrm{r}-\mathrm{GO} / \mathrm{CNT}$ /p-GaN and $\mathrm{Au} / \mathrm{Pd} / \mathrm{r}-\mathrm{GO} / \mathrm{CNT} / \mathrm{p}-\mathrm{GaN}$ contact structures in dependence on the temperature of annealing in nitrogen are shown in Figs. 4 and 5. The nearly linear shape of the $I-V$ curves of the two structures proves their ohmic nature, even prior to any annealing procedure. Evaluation of the $I-V$ curves mainly from the point of view of their slope and linearity reveals the optimum annealing in $\mathrm{N}_{2}$ temperature to be $700{ }^{\circ} \mathrm{C}$ for 1 minute. In the case of the $\mathrm{Au} / \mathrm{Pd} / \mathrm{r}-\mathrm{GO} / \mathrm{CNT} / \mathrm{p}-\mathrm{GaN}$ contact structure the optimum annealing is in air for 1 minute. In this case the $I-V$ curve is linear as proved by the corresponding line in Fig. 5. It has been found [15] that the structure containing the CNT interlayer exhibits lower values of contact resistance in comparison with an otherwise identical contact without the CNT interlayer. The $I-V$ curve of the $\mathrm{Au} / \mathrm{Pd} / \mathrm{r}-\mathrm{GO} / \mathrm{CNT} / \mathrm{p}-\mathrm{GaN}$ contact structure annealed in air at $500^{\circ} \mathrm{C}$ for 1 minute proves that addition of r-GO to the CNT interlayer is a promising solution for further improvements of the ohmic contacts to p-GaN.

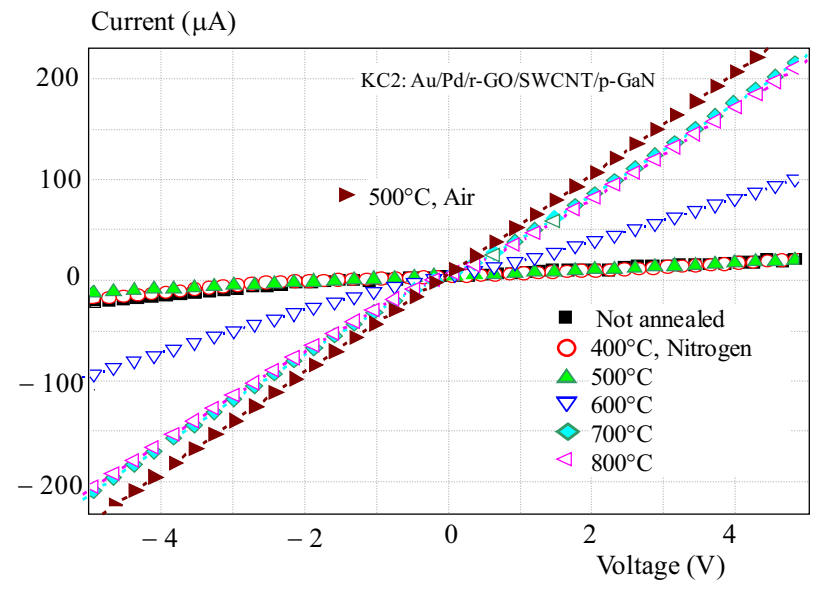

Fig. 5. $I-V$ curves of the $\mathrm{Au} / \mathrm{Pd} / \mathrm{r}-\mathrm{GO} / \mathrm{CNT} / \mathrm{p}-\mathrm{GaN}$ contact nonannealed and annealed in $\mathrm{N}_{2}$ at temperatures ranging from 400 to $800{ }^{\circ} \mathrm{C}$ and in air at $500{ }^{\circ} \mathrm{C}$ for 1 minute

\section{CONCLUSIONS}

We have studied two novel contact structures, namely $\mathrm{Au} / \mathrm{Cr} / \mathrm{r}-\mathrm{GO} / \mathrm{CNT} / \mathrm{p}-\mathrm{GaN}$ and $\mathrm{Au} / \mathrm{Pd} / \mathrm{r}-\mathrm{GO} / \mathrm{CNT} / \mathrm{p}-$ $\mathrm{GaN}$ based on a layer of reduced graphene oxides, carbon nanotubes and metallic layers $\mathrm{Au} / \mathrm{Cr}, \mathrm{Au} / \mathrm{Pd}$ for ohmic contacts to $\mathrm{p}-\mathrm{GaN}$, particularly for application in light emitting devices. It has been found that both of the contact structures exhibit ohmic properties even prior to any annealing treatment. Comparison of the I-V curves from the point of view of their slopes and linearity proves that in the case of the $\mathrm{Au} / \mathrm{Cr} / \mathrm{r}-\mathrm{GO} / \mathrm{CNT} / \mathrm{p}-\mathrm{GaN}$ contact the best thermal treatment is annealing in nitrogen at $700{ }^{\circ} \mathrm{C}$ for 1 minute. Annealing of the $\mathrm{Au} / \mathrm{Pd} / \mathrm{r}-\mathrm{GO} / \mathrm{CNT} / \mathrm{p}$ $\mathrm{GaN}$ structure in air at $500{ }^{\circ} \mathrm{C}$ for 1 minute resulted in a linear $I-V$ curve, hence addition of r-Go to the CNT intermediate layer between p-GaN and the metallization is a highly promising solution for further improvements of the ohmic properties of the contacts to $\mathrm{p}-\mathrm{GaN}$.

\section{Acknowledgement}

The work was supported by the Scientific Grant Agency of the Ministry of Education of the Slovak Republic and of the Slovak Academy of Sciences VEGA No. 1/1197/12 and by grant of Slovak Research and Development Agency No. APVV-0455-12.

\section{REFERENCES}

[1] MURAKAMI, M.-KOIDE, Y. Ohmic Contacts for Compound Semiconductors Critical Reviews: Solid State and Materials Sciences 23 (1998), 1-60.

[2] WENZEL, R.-FISCHER, G. G.-SCHMID-FETZER, R. : Ohmic Contacts on p-GaN (Part I): Investigation of Different Contact Metals and their Thermal Treatment, Materials Science in Semiconductor Processing 4 (2001), 357-365.

[3] HO, J. K.-JONG, C. S.-CHIU, C. C.-HUANG, C. N.-SHIH K. K.-CHEN, L. C.-CHEN, F. R.-KAI, J. J. : Low Resistance Ohmic Contacts to p-type GaN Achieved by the Oxidation of Ni/Au Films, Journal of Applied Physics 86 (1999), 4491-4497. 
[4] Mistele, D.-FedLeR, F.-KLAusing, H.-ROTTER, T.-STEMMER, J.-SEMCHINOVA, O. K.-ADERHOLD, $\mathrm{J}$. : Investigation of $\mathrm{Ni} / \mathrm{Au}$-contacts on $\mathrm{p}-\mathrm{GaN}$ Annealed in Different Atmospheres, Journal of Crystal Growth 230 (2001), $564-568$.

[5] JANG, H. W.-KIM, S. Y.—LEE, J.-L. : Mechanism for Ohmic Contact Formation of Oxidized $\mathrm{Ni} / \mathrm{Au}$ on p-type GaN, Journal of Applied Physics 94 (2003), 1748-1752.

[6] LIDAY, J.-HOTOVÝ, I.-SITTER, H.-VOGRINČIČ, P.VINCZE, A.-VÁVRA, I.-ŠATKA, A.-ECKE, G.-BONANNI, A.-BREZA, J.-SIMBRUNNER, C.-PLOCHBERGER, B. : Investigation of $\mathrm{NiO}_{x}$-based Contacts on p-GaN, Journal of Materials Science: Materials in Electronics 19 (2008), 855-862.

[7] SONG, J.-O.-LEEM, D.-S.-SEONG, T.-Y.: Formation of Low Resistance and Transparent Ohmic Contacts to p-type GaN Using NiMg Solid Solution, Applied Physics Letters 83 (2003), 3513-3515.

[8] SONG, J.-O.-LEEM, D.-S.-SEONG, T.-Y.: Low-resistance and Transparent Ohmic Contacts to p-Type GaN Using ZnNi Solid Solution/Au Scheme, Applied Physics Letters 84 (2004), 4663-4665.

[9] LIDAY, J.-VOGRINČIČ, P.-VINCZE, A.—BREZA, J.-HOTOVÝ, I.: Improving the Ohmic Properties of Contacts to p-GaN by Adding p-type Dopants into the Metallization Layer, Journal of Electrical Engineering 63 (2012), 397-401.

[10] ZAHAB, A.-SPINA, L.-PONCHARAL, P.-MARLIRE, C. : Water-vapor Effect on the Electrical Conductivity of a Single-walled Carbon Nanotube, Mat Physical Review No. B62 (2000), 10 000-10 003.

[11] LEE, K.-WU, Z.-CHEN, Z.-PEARTON, S. J.-RINZLER, A. G.: Single Wall Carbon Nanotubes for p-type Ohmic Contacts to GaN Light-emitting Diodes, Nano Letters No. 4 (2004), 911-914.

[12] DERYCKE, V.-MARTEL, R.-APPENZELLER, J.-AVOURIS, PH. : Controlling Doping and Carrier Injection in Carbon Nanotube Transistors, Applied Physics Letters 80 (2002), $2773-2775$.

[13] ANTONOV, R. D.-JOHnSON, A. T.: Subband Population in a Single-wall Carbon Nanotube Diode, Physical Review Letters 83 (1999), 3274-3276.

[14] LIDAY, J.-VOGRINČIČ, P.—VRETENÁR, V.-KOTLÁR, M.-VÁVRA, I.-HOTOVÝ, I.-BREZA, J.—ŘEHÁČEK, V. : The Layers of Carbon Nanomaterials as the Base of Ohmic Contacts to p-GaN, Applied Surface Science 312 (2014), 63-67.

[15] PHAM, T. A.-KIM, JEONGSIK-KIM, JEONGSU—JEONG, Y. T. : One-step Reduction of Graphene Oxide with L-glutathionev Colloids and Surfaces, A: Physicochemical and Engineering Aspects 384 (2011), 543-548.

[16] SKÁKALOVÁ, V.-VRETENÁR, V.—KOPERA,.-L'KOTRUSZ, P.-MANGLER, C.-MEŠKO, M.-MEYER, J. C.-HUL-
MAN, M.: Electronic Transport in Composites of Graphite Oxide with Carbon Nanotubes, Carbon 72 (2014), 224-232.

17] KINDER, R.-MIKOLÁŠEK, M.-DONOVAL, D.-KOVÁČ, J.-TLACZALA, M. : Measurement System with Hall and Four Point Probes for Characterization of Semiconductors, Journal of Electrical Engineering 67 (2013), 106-111.

Received 15 March 2014

Jozef Liday (Assoc Prof, PhD) graduated in solid state physics in 1968 and received his $\mathrm{PhD}$ in electronics and vacuum technology, both from STU, in 1985. His teaching and research activities include materials analysis, thin films and surface science.

Peter Vogrinčič (Ing) graduated in radioelectronics from the Slovak University of Technology in 1992. He is engaged in research, particularly in Auger analysis and depth profiling.

Viliam Vretenár (Ing, $\mathrm{PhD}$ ) graduated in electromaterial engineering from STU in 2000 and received the $\mathrm{PhD}$ degree in condensed matter physics and acoustics from the Institute of physics SAS in 2006. He is engaged in application of CNTs and graphene in nanodevices, such as gas sensors, transparent conductive layers, supercapacitors, etc.

Mário Kotlár (Ing, $\mathrm{PhD}$ ) graduated in electronics from STU in 2010. He is a research worker in the field of carbon nanotubes at the Institute of Electronics and Photonics, FEIT STU. His work mainly deals with deposition and analysis of CNTs and other carbon nanomaterials.

Marián Marton (Ing, PhD) graduated in electronics in 2004 and in 2008 he received his $\mathrm{PhD}$ in electronics and vacuum technology, both from STU. Currently his research deals with carbon nanomaterials, eg, diamond, CNTs, CNWs and DLC.

Miroslav Mikolášek (Ing, $\mathrm{PhD}$ ) graduated in electronics in 2007 and received his $\mathrm{PhD}$ degree in electronics from the Slovak University of Technology in 2011. At present he works at the Institute of Electronics and Photonics, Slovak Technical University in Bratislava. His main research interests include simulation and diagnostics of solar cells based on amorphous silicon.

Vlastimil Řeháček (RNDr, PhD) graduated in nuclear chemistry from Comenius University in Bratislava in 1982 and received his $\mathrm{PhD}$ in electronics from the Slovak University of Technology in 2005. He is a scientific worker at the Institute of Electronics and Photonics. His current research interests include the development of voltammetric sensors, gas sensors and photolithography. 